\title{
PEDAGOGICAL COMMUNICATION AND PRACTICAL USE METHOD OF FIAS
}

\section{Martina REŠKOVÁ}

\begin{abstract}
The contribution deals with the pedagogical communication with the help of interactive boards and Flander's interactive analysis system. In this contribution we will focus on the term of communication and interaction which goes hand in hand with communication. Then we will devote time to pedagogical communication which is one of the means of communication. We will also mention technical means of communication and the possibilities of communication research in class using the Flander's method.
\end{abstract}

Key words: communication, pedagogical communication, interaction, Flander's method.

\section{PEDAGOGICKÁ KOMUNIKACE A PRAKTICKÉ UŽITÍ METODY FIAS}

Resumé: Př́spěvek se zabývá pedagogickou komunikací pomocí interaktivní tabule a použití Flandersovy metody interakční analýzy. V př́spěvku se zaměříme nejprve na pojem komunikace a interakce, která s komunikací souvisí. Poté se budeme věnovat pedagogické komunikaci, která je jednou $\mathrm{z}$ forem komunikace. Zmíníme se o technických prostředcích v komunikaci a možnostmi zkoumání komunikace ve tř́dě za pomocí Flandersovy metody.

Klíčová slova: komunikace, pedagogická komunikace, interakce, Flandersova metoda.

\section{1 Úvod}

Komunikace je základním prostředkem k uskutečnění jakéhokoliv výukového procesu. Nezáleží na tom, zda se jedná o komunikaci př́mou mezi učitelem a žáky, nebo studium žáka $\mathrm{z}$ učebního textu, anebo $\mathrm{v}$ rámci komunikace využíváme moderních technických prostředků. Vždy se jedná o sdělování a přijímání informací, a tedy o komunikaci. Proto se pedagogická komunikace stala předmětem mnoha výzkumů, které se jí snaží popisovat a objasňovat (1).

\section{Komunikace}

Pojem komunikace se vyskytuje $v$ rozmanitosti interpretací. Komunikace má též mnoho různých významů, a to proto, že můžeme komunikovat v různých situacích, ve kterých sledujeme odlišné cíle a dospíváme pokaždé k jiným výsledkům komunikace. Původ slova komunikace vychází z latinského communicare, což v překladu znamená informovat, oznamovat, radit se s někým. V souvislosti s komunikací se hodně často používá pojem interakce. Interakci můžeme definovat jako vzájemné působení nebo též ovlivňování. Jedná se oboustrannou komunikaci (2).

Interakce a komunikace jsou př́buzné pojmy, ale nejsou totožné. Komunikace je nástroj pro realizaci interakce a také samotná komunikace umožňuje interakci (3). Samotná interakce se nemusí uskutečňovat pouze slovem, ale lze ji uskutečňovat také konáním, činy, předměty apod. Interakce se může uskutečnit i zprostř̌edkovaně, a to prostřednictvím média.

Interakce a komunikace mají $\mathrm{k}$ sobě velmi blízko, avšak je potřeba si uvědomit, že interakce (působení, vliv) je spíše sociálně-psychologická záležitost, naproti tomu komunikace je činnost sociálně-informační, která se realizuje za pomocí jazykových a nejazykových prostředků (2).

\section{Pedagogická komunikace}

Jednou $\mathrm{z}$ forem komunikace je pedagogická komunikace, která probíhá mezi učitelem a žáky. Komunikace ve trrídě má mnoho zvláštností, kterými se odlišuje od komunikace $\mathrm{v}$ jiných institucích apod. Tato odlišnost je daná rolemi partnerů v komunikaci, cílem komunikace, obsahem komunikace, ale též časovými a prostorovými dispozicemi (2).

Pedagogická komunikace má tyto hlavní aspekty:

- uskutečňuje se za pomocí verbálních a neverbálních projevů jako sled komunikačních aktů a situací; 
- ř́ídí ji učitel a má specifická pravidla, která vymezují roli a pravomoc účastníků komunikace;

- plní různé funkce: je určena $\mathrm{k}$ prezentaci obsahu vzdělání, k uskutečňování cílů výchovy a vzdělávání, k řízení třídy, k navozování vztahů mezi učiteli a žáky, k sdělování informací, které se nevztahují prímo k výuce;

- vytváŕí konkrétní psychosociální klima ve třídě a zároveň je úrovní tohoto klimatu ovlivňována;

- má specifické charakteristiky ve školách jednotlivých zemí v závislosti na typu národní kultury (1).

\section{Technické prostředky $v$ komunikaci}

Žák používá při učení učebnice, encyklopedie, př́ručky, časopisy apod. Často používá také technická zařízení: video, televizi, CD nosiče a počítačové zpracované programy. Jde tedy o textový, obrazový a zvukový materiál (2). V poslední době při rozvoji moderních technických prostředků se stává součástí technických zařizení, které žák používá při učení také interaktivní tabule, která dokáže propojit textový, obrazový a zvukový materiál.

\section{Jak se zkoumá komunikace ve tř́ídě}

Zkoumání a hodnocení komunikace ve třídě je velmi důležitým zdrojem poznání pro teoretika, ale cennějším pro samotného učitele. Existuje mnoho metod sledování komunikace ve třídě. Nejpřirozenější metodou je pozorování, př̀i kterém je pozorovatel přítomný ve třídě, zapisuje si poznámky o průběhu komunikace a dochází $\mathrm{k}$ závěrům.

Některá pozorování jsou založena na analýze autentických výroků žáků a učitele, v tomto prŕípadě je nutnost výroky přesně zaznamenávat. Etnografové užívají zúčastněné pozorování, účastní se různých aktivit, vedou se žáky a učiteli neformální rozhovory, aby pochopili kulturu tř́́dy. Pozorovatel má sice určitý záměr a cíl, ale jeho pozorování nemá žádnou osnovu nebo schéma. Proto takové pozorování nazýváme nestrukturované.

Naopak při strukturovaném pozorování má pozorovatel dopředu prripravený rámec pozorování. Jedná se o přesně definované pozorované kategorie - typy činností, které sleduje. Pozorovatel si značí frekvenci a četnost těchto činností. Pro vyhodnocení získá velmi přesný kvantitativní obraz o průběhu komunikace ve trrídě. Pozorovatel si připraví systém pozorovacích kategorií podle vlastních cílů nebo využije osvědčené nástroje. Př́kladem tohoto pozorování je Flandersův pozorovací systém (FIAS), který uvádíme v následující kapitole (2).

\section{Flandersův pozorovací systém}

Flandersův systém (FIAS) se používá na pozorování a vyhodnocení komunikace ve třídě. Jeho největší předností je jednoduchost. Obsahuje deset kategorií jevů, lze ho použít při frontálním vyučování, ale nehodí se na skupinové nebo individuální vyučování.

Flandersův systém vyšel $\mathrm{z}$ teorie $\mathrm{o}$ tzv. prímém a neprímém vlivu učitele. Přímý vliv učitele redukuje žákovu volnost. Nepřímý vliv učitele vede ke zvýšení žákovy volnosti.

Pozorovatel sleduje vyučovací hodinu a každou třetí sekundu učiní záznam kategorie (Tab. 1), která se právě vyskytla. Takovým způsobem lze provést prímé pozorování vyučovací hodiny nebo nepř́ímé pozorování (z nahrávky). Alternativně lze tento systém používat s přirozeným kódováním, kdy si pozorovatel udělá záznam vždy, když zpozoruje výskyt jevu patřící do určité kategorie (2). 
Tab. 1: Kategorie Flandersova pozorovacího systému

\begin{tabular}{|c|c|}
\hline \multirow[t]{7}{*}{ Řeč učitele } & $\begin{array}{l}\text { 1. Akceptuje žákovy } \\
\text { city. }\end{array}$ \\
\hline & 2. Chválí a povzbuzuje. \\
\hline & $\begin{array}{l}\text { 3. Akceptuje myšlenky } \\
\text { žáka nebo je rozvíjí. }\end{array}$ \\
\hline & 4. Klade otázky. \\
\hline & 5. $\quad$ Vysvětluje. \\
\hline & $\begin{array}{l}\text { 6. Dává pokyny nebo } \\
\text { príkazy. }\end{array}$ \\
\hline & $\begin{array}{c}\text { 7. Kritizuje nebo } \\
\text { prosazuje vlastní autoritu. }\end{array}$ \\
\hline \multirow{2}{*}{ Řeč žáka } & 8. Odpovídá. \\
\hline & 9. Hovoří spontánně. \\
\hline
\end{tabular}

Zdroj: GAVORA, P. Učitel a žáci v komunikaci. Brno: Paido. 2005. s. 151. ISBN 80-7315-104-9.

Pokud bychom chtěli Flandersovu metodu rozšírit na interaktivní tabuli, tak je nutné jednotlivé kategorie tak, aby vyhovovaly právě komunikaci s interaktivní tabulí. Je možné upravit původní kategorie Flandersovy metody o přidání prvků práce $\mathrm{s}$ interaktivní tabulí, např̀. student aktivně pracuje s interaktivní tabulí (dle zadání), přidává poznámky nebo vyjadřuje vlastní názor apod.

Kategorie Flandersovy metody lze celkově přizpůsobit práci s interaktivní tabulí např́. následujícím způsobem:

Učitel:

- $\quad$ bere pero a píše na interaktivní tabuli;

- pomocí animace na interaktivní tabuli vysvětluje učivo;

- používá zvukovou nahrávku na interaktivní tabuli.

Žák (student):

- plní úkoly za pomocí zvukové nahrávky na interaktivní tabuli;

- $\quad$ pomocí pera píše na interaktivní tabuli;

- pohybuje s nabídkami na interaktivní tabuli.

Stanovit tyto prvky dopředu a s rozmyslem je rozhodující pro praktické využití Flandersovy metody pomocí interaktivní tabule.

\section{Závěr}

$\mathrm{V}$ př́spěvku jsme se zaměřili na komunikaci a komunikaci ve vyučovacím procesu, tj. pedagogickou komunikaci, která je základním prostředkem realizace výchovy a vzdělávání. Zmínili jsme se rovněž o Flandersově metodě, která vznikla v minulém století, ale je pořád aktuální a stále využívaná na pozorování a vyhodnocování komunikace ve trrídě.

\section{Literatura}

[1] PRŮCHA, J. (ed.). Pedagogická encyklopedie. Praha: Portál, 2009. 936 s. ISBN 978-80-7367-546-2.

[2] GAVORA, P. Učitel a žáci v komunikaci. Brno: Paido, 2005. 165 s. ISBN 80-7315-104-9.

[3] JANOUŠEK, J. Společná činnost a komunikace. Praha: Svoboda, 1984. 242 s. Sociologická knižnice.

Lektoroval: PhDr. Radka Dofková, Ph.D.

Martina Rešková, Mgr.,

Katedra technické a informační výchovy, Pedagogická fakulta UP, Žižkovo nám. 5, 77140 Olomouc, ČR, tel. 00420585635819 , e-mail: martina.reskova@gmail.com 